Chapter 10

\title{
Eye Infection Complications in Rheumatic Diseases
}

\author{
Brygida Kwiatkowska and Maria Maślińska
}

Additional information is available at the end of the chapter

http://dx.doi.org/10.5772/52968

\section{Introduction}

Rheumatic diseases are a group of illnesses characterized by the inflammation of the connective tissue, usually of autoimmunological origin. Although most of the symptoms of the rheumatic diseases concern primarily musculoskeletal system, in many of these disorders pathological changes take also place in various other organs. Changes in the organ of sight in the rheumatic diseases may result from the inflammatory process taking place in the course of immunological dysfunctions and their manifestations may precede typical in these illnesses musculoskeletal symptoms. Damage to the organ of sight may also be secondary to vascular lesions occurring in the course of its inflammation or may be the result of complications arising from the therapy of the rheumatic disease. (Table 1).

\begin{tabular}{ll}
\hline Rheumatic diseases with arthritis & Rheumatoid arthritis \\
& Spondyloarthropathies: \\
& Ankylosing spondylitis \\
& Psoriatic arthritis \\
& Reactive arthritis \\
& Arthritis associated with inflammatory bowel disease \\
& (Colitis ulcerosa, Leśniowski - Crohn's disease) \\
& undifferentiated spondyloarthropathy \\
& Juvenile idiopathic arthritis \\
\hline Connective tissue diseases & Systemic lupus erythematosus \\
& Sjogren's syndrome \\
Systemic scleroderma & relapsing polychondritis \\
\end{tabular}




\begin{tabular}{ll}
\hline Systemic vasculitis & Polyarteritis nodosa \\
& Churg-Strauss syndrome \\
& Wegener's granulomatosis \\
Behçet's disease & Takayasu's disease \\
Giant cell arteritis & Cogan syndrome
\end{tabular}

Table 1. Rheumatic diseases with changes occurring in the organ of sight.

\section{Characteristics of rheumatic diseases, in which the most frequent changes in the organ of sight occur}

The rheumatoid arthritis (RA) and spondyloarthropathies (SpA) are the most common inflammatory rheumatic diseases. Significantly less frequently uvenile idiopathic arthritis (JIA), Sjögren's syndrome (SS), systemic lupus erythematosus (SLE) and other less frequent connective tissue diseases as scleroderma, dermato-and polymiositis, recurrent inflammation of the cartilage and systemic vasculitis are observed.

\subsection{Rheumatoid arthritis}

Rheumatoid arthritis is an autoimmune connective tissue disease that manifests itself mostly with symmetrical swelling of the joints (particularly of the hands) - and with morning stiffness. The incidence of RA in the world is estimated at about $0.33-1.5 \%$ of the total population $[1,2,3,4,5,6]$. The diagnosis of RA is based on the current 2010 ACR / EULAR criteria. The diagnosis of RA is definite when the summary point record for all criteria $(A+B+C+$ D) reaches $\geq 6$ out of 10 . (Table 2 ) [7].

\begin{tabular}{lll}
\hline A. Joint involvement & 1 large joint & 0 \\
& $2-10$ large joints & 1 \\
& $1-3$ small joints (with or without involvement of large 2 \\
& joints) & 3 \\
& $4-10$ small joints (with or without involvement of & 5 \\
& joints) & "/ 10 joints (at least 1 small joint affected) \\
\hline B. serological tests (at least one required) & Negative results for the presence of RF and ACPA & 0 \\
& Positive results in the presence of low-titer RF and 2 \\
& ACPA \\
& Positive results in the presence of high titers of RF \\
& and ACPA
\end{tabular}




\begin{tabular}{lll}
\hline C. indicators of acute fase ( at least one required) & Valid values for CRP and ESR & 0 \\
& Incorrect values of CRP and ESR & 1 \\
\hline D. duration of symptoms & $<6$ weeks & 0 \\
& $\geq 6$ weeks & 1 \\
\hline
\end{tabular}

RF - Rheumatoid Factor, ACPA - Anti-Citrullinated Protein Antibodies, CRP - C-Reactive Protein, ESR - Erythrocyte Sedimentation Rate

Table 2. ACR/EULAR 2010 classification criteria for rheumatoid arthritis

Approximately $40 \%$ of patients with RA present not only joint inflammation but also clinical symptoms resulting from other organ involvement [8].

Frequently, in as many as about $30 \%$ of patients with rheumatoid, rheumatoid nodules occur [9]. The changes in the lungs, such as pleural involvement, take place in approximately $50 \%$ of patients, but only in $10 \%$ of cases are identified [10]. Similarly frequently autopsy reveals changes in the heart.

In echocardiography pericardial effusion is revealed in $31 \%$ of patients [11]. $1-5 \%$ of patients with RA are diagnosed with vasculitis, while autopsy studies detect these changes in $15-31 \%$ of patients $[12,13]$. Changes in the eyes in the course of RA are observed in approximately $25 \%$ of patients $[14,15]$. The treatment of RA is based on disease-modifying drugs (DMARDs) such as methotrexate, sulfasalazine. leflunomide, cyclosporine, cyclophospamide, hydroxychloroquine or chloroquine and gold salts. Furthermore, patients often have glucocorticoids and nonsteroidal anti-inflammatory drugs (NSAIDs) administered orally or locally (intra-articularly). In the contemporary rheumatology in case of ineffectivness of the traditional DMARDs therapy second line treatment is implemented - based on biological agents. These include TNFalpha (tumor necrosis factor) inhibitors such as adalimumab, certolizumab pegol, etanercept, golimumab, infliximab as well as drugs with other mechanism of action such as abatacept (antiCTL-4), rituximab (anti-CD 20) and tocilizumab (anti-IL-6) [16].

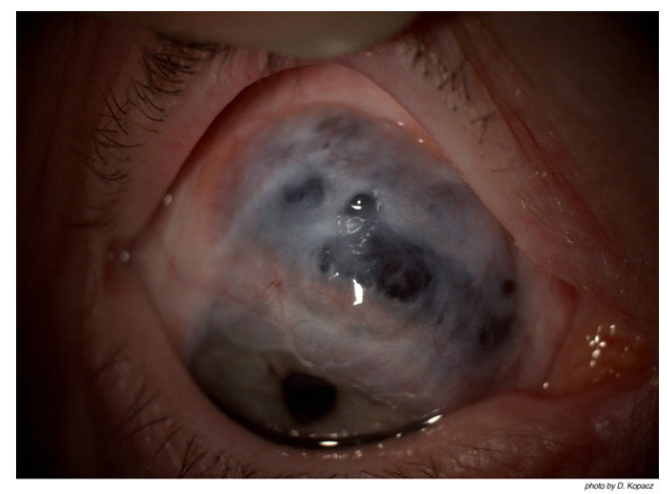

Figure 1. Scleromalacia perforans in patient with long-term RA (photo by D. Kopacz). 


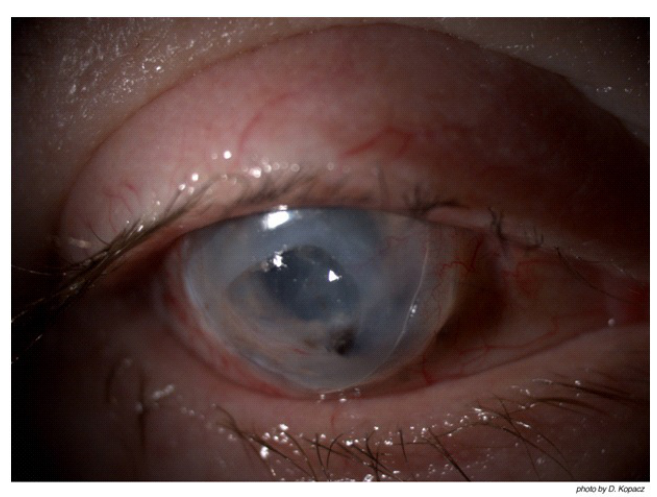

Figure 2. Scleromalacia perforans in patient with long-term RA (photo by D. Kopacz).

\subsection{Spondyloarthropathies}

Spondyloarthropathies $(\mathrm{SpA})$ are a group of diseases are characterized by similar clinical symptoms and genetic predispositions.

Back pain lasting $\geq 3$ months with the start in $<45$ years of age (with or without periferal symptoms of the disease

\begin{tabular}{|c|c|c|}
\hline $\begin{array}{l}\text { Sacroiliitis in imaging tests results } \\
\qquad 1 \\
\geq 1 \text { symptom of } \\
\text { spondyloarthropathy }\end{array}$ & or & $\begin{array}{l}\text { Presence of HLAB27 } \\
\text { antigen } \\
\geq 2 \text { symptoms of } \\
\text { sDondvloarthropathv }\end{array}$ \\
\hline
\end{tabular}

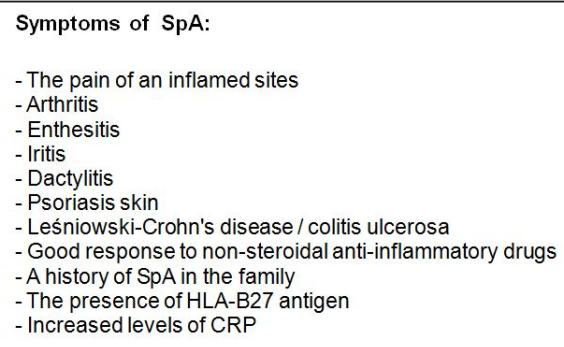

Table 3. ASAS classification criteria for axial spondyloarthropathy 
Spondyloarthropathies can be divided into 2 groups according to the predominant symptoms. The domination of symptoms suggestive of spinal involvement, such as inflammatory back pain (IBP) - i.e. pain escalating at night, decreasing after exercise, not alleviated by the period of rest - defines axial spondyloarthropathy. In patients with prevalence to enthesitis and peripheral arthritis, the peripheral sopndyloarthropathy is diagnosed. ASAS Group (Ankylosing spondylitis In Assessment) has developed diagnostic criteria common to these diseases (Table 3.4) [17, 18].

Peripheral arthritis (most commonly of the lower extremities and/or asymmetrical) or enthesitis (enthesitis), or sausage fingers (dactylitis)

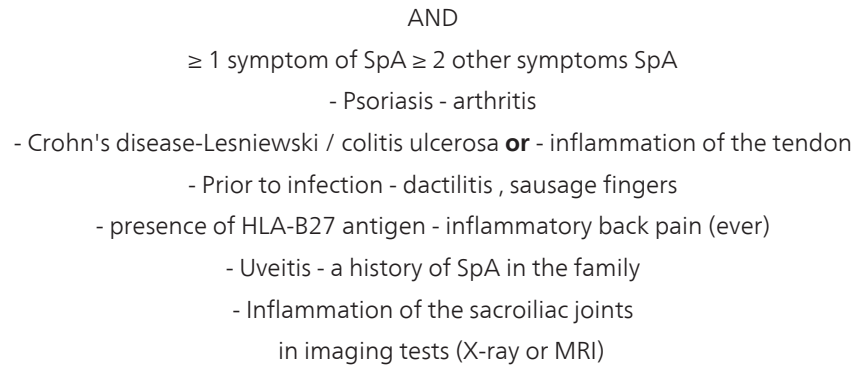

Table 4. ASAS classification criteria for peripheral spondyloarthropathy

There separate classification criteria for particular spondyloarthropathies such as ankylosing spondylitis (AS), psoriatic arthritis (PsA), reactinve arthritis (ReA), arthritis in course of ulcerative colitis and Leśniowski- Crohn's disease are also established.

Spondyloarthropathies incidence is similar to that of RA and ranges from 0.15 to $1.8 \%$ of the general population $[19,20,21]$.

The uveitis affects approximately $0.5 \%$ of patients with spondyloarthropathies, and frequency of its occurence varies depending on the type of spondyloarthropathies. In AS uveitis occurs in $0.8 \%$ of patients, while in about $2.3 \%$ of patients with the PsA [22]. Ocular changes in SpA related to non-specific inflammatory bowel disease (ulcerative colitis, Leśniowski Crohn's disease) occur in up to $4-12 \%$ of patients $[23,24]$.

Conjunctivitis occurs in 33-100\% of patients with reactive arthritis [25] and 20 to $33 \%$ of patients with PsA [26].

The treatment of spondyloarthropathies is based on non-steroidal anti-inflammatory drugs, disease-modifying drugs such as methotrexate, leflunomide, sulfasalazine, cyclosporyna and biological agents from the group of anti-TNF-alpha. The glucocorticoids are also used in intraarticular injections [27,28]. 


\subsection{Juvenile idiopathic arthritis}

Juvenile idiopathic arthritis is the most common form of chronic inflammation of the connective tissue in children. Prevalence in the population is 43-148 cases per 100000 persons $[29,30,31]$. The diagnosis of JIA is based on the 1997 ILAR criteria. For the arthritis do be diagnosed as JIA the onset of the disease must take place until 16 years of age, arthritis symptoms must last more than 6 weeks and other diseases in which arthritis occurs have to be excluded (e.g.infectious, reactive, toxic and allergic and neoplastamatic diseases and other conditions with joint involvment). Ocular complications - mainly uveitis - occur in approximately $12-17 \%$ of juvenile patients [32]. Treatment, as in RA, is based on DMARDs and biological agents.

\subsection{Systemic lupus erythematosus (SLE)}

Systemic lupus erythematosus (SLE) is a chronic inflammatory autoimmune disease with diverse symptomatology resulting from involvement of many organs and systems. The prevalence of SLE in the general population ranges from 0.016 to $0.092 \%[33,34,35]$. The typical clinical features of SLE include facial erythema, discoid rash, photosensitivity, oral ulcers, arthritis, pleurisy or pericarditis, kidney changes, changes in the central nervous system, haematological disorders (such as hemolytic anemia, leukopenia, lymphopenia, thrombocytopenia), immune changes with presence of antinuclear, anti-DNA and anti-Sm autoantibodies, as well as false positive syphilis tests. SLE may be associated with antyphospolipid syndrome (APS) with thrombotic episodes in the arteries and veins and obstetrics failure in women. Diagnosis is based on the revised 1997 ACR classification criteria [36]. Changes in the organ of sight occur in approximately $25 \%$ of patients, mainly in the course of secondary Sjögren's syndrome but also as result of vasculitis and thrombosis [37]. Conjunctivitis, episcleritis and interstitial keratitis are rare [38].

\subsection{Primary Sjögren's syndrome}

Primary Sjögren's syndrome (pSS) is an inflammatory autoimmune disease that occurs most often in women between 40 and 50 years of age. The clinical symptoms of the disease result from B cell autoreactivity, polyclonal immunoglobulin overproduction and infiltration of exocrine glands by lymphocytes (CD4 cells predominate). The dominant symptom is dryness of the mouth and eyes. The nonerosive arthritis, vasculitis, peripheral neuropathy and different symptoms from central nervous system are also observed in pSS. According to different data Sjögren's syndrome prevalence rate ranges from 0.2 to $13.3 \%$ of the population [39,40,41]. Sjögren's syndrome is diagnosed on the basis of the revised 2002 American-European criteria[42]. Ocular symptoms associated with impaired secretion of tears occur in all patients with Sjögren's syndrome - either in the initial or more advanced stages of the dis- 
ease - and constitute one of to the diagnostic criteria. Treatment is based on the use of both symptomatic drugs - moistening eyes and mouth - and of immunosuppressants.

\subsection{Scleroderma}

Scleroderma is an inflammatory connective tissue disease of unknown etiology characterized by the damage to blood vessels, the presence of autoantibodies (SCL 70 or anticentromeric autoantibodies for diffuse systemic sclerosis and localised systemic sclerosis respectively) and progressive fibrosis of the skin and internal organs. Systemic sclerosis prevalence rate in the world is ranging from $0.0007 \%$ to $0.265 \%$ [43,44,45]. Disease diagnosis based on the classification and diagnostic criteria of the 1980 ACR [46]. $71 \%$ of patients present changes in blood and conjunctival subepithelial fibrosis. In course of SS all structures of the eye may be affected $[47,48]$. Patient with SS may develop secondary Sjogren's syndrome and symptoms of dry eye, as well as complications due to the dryness of the conjunctiva [49].

\subsection{Recurrent inflammation of the cartilage}

Recurrent inflammation of the cartilage is a rare inflammatory autoimmune disease in which the inflammatory process involving mostly cartilage, causing changes and dysfunction of many tissues and organs. Onset of the disease usually affects people of 40-60 years of age and the prevalence of this disease in the world is estimated at about 3 cases per 1 million people in the population [50]. Currently, the diagnosis of this disease can be based on the diagnostic criteria of McAdam, 1976 [51]. Changes in the organ of vision occur in approximately $60 \%$ of patients and may include almost all structures of the eye $[52,53]$.

\subsection{Systemic vasculitis}

In the course of systemic vasculitis such as polyarteritis nodosa, Churga-Strauss syndrome, Wegener's granulomatosis, Behçet's disease, Takayasu disease, giant cell arteritis and Cogan syndrome there are changes in the organ of sight secondary to vascular changes. In polyarteritis nodosa ocular changes are observed in approximately $10-20 \%$ of patients [54,55], in Wegener's granuloma in $28-58 \%$ of patients [56,57] Behçet's disease in $68-85 \%$ of patients $[58,59,60]$. The ocular changes in course of inflammation of the large vessels, such as giant cell arteritis, are mainly associated with ischemia of optic nerve or retina. Ischemia causes impairment of vision and blindness, which may occur in 13 to $70 \%$ of patients $[61,62]$. The treatment of all systemic vasculitis requires agressive immunosuppressive therapy and high doses of glucocorticoids. In somecasesof very active diseaseand noreaction toother treatment, especially incaseofWegener's granuloma, biological therapy (rituximab) is used [63,64] 


\section{Characteristic changes in the organ of sight in rheumatic diseases}

The pathological changes can occur in all elements of the organ of sight in the course of rheumatic diseases. These can cause temporary or permanent damage (Table 5). Changes in the eyes are the first symptom of rheumatic fever observed in approximately $4 \%$ of patients [65].

\begin{tabular}{|c|c|}
\hline type of symptoms and changes in the eye & rheumatic disease \\
\hline \multirow[t]{2}{*}{ conjunctivitis } & Reactive arthritis \\
\hline & Psoriatic arthritis \\
\hline \multirow[t]{4}{*}{ dryness } & Sjögren's syndrome \\
\hline & Rheumatoid vasculitis \\
\hline & Rheumatoid arthritis \\
\hline & Systemic vasculitis \\
\hline Uveitis: & Spondyloarthropathies \\
\hline Acute anterior uveitis & Behçet disease \\
\hline Chronic anterior uveitis & colitis ulcerosa/ Leśniowski - Crohn's disease \\
\hline \multirow[t]{3}{*}{ Panuveitis } & colitis ulcerosa/ Leśniowski-Crohn;s disease \\
\hline & relapsing polychondritis \\
\hline & Behçet disease \\
\hline \multirow[t]{4}{*}{ Scleritis } & Rheumatoid arthritis \\
\hline & systemic vasculitis \\
\hline & Colitis ulcerosa/ Leśniewski- Crohn;s disease \\
\hline & Relapsing polychondritis \\
\hline Keratitis: & Sjögren's syndrome \\
\hline Non-necrotizing corneal melt & Rheumatoid vasculitis \\
\hline \multirow[t]{2}{*}{ Necrotizing keratitis } & Rheumatoid arthritis \\
\hline & systemic vasculitis \\
\hline Retinal vasculopathy & Systemic Lupus erythematosus \\
\hline Microvasculopathy & Systemic lupus erythematosus \\
\hline \multirow[t]{2}{*}{ Diffuse vaso-occlusive disease } & Antiphospholipid syndrome \\
\hline & Behçet disease \\
\hline Optic nerve disaease & Systemic vasculitis (particulary giant cell vasculitis) \\
\hline Ischemic optic neuropathy & \\
\hline
\end{tabular}

Table 5. The most common ocular changes in the course of the rheumatic diseases.

Changes in the eyes in course of the rheumatic diseases may also be caused by the implemented treatment. Nonsteroidal anti-inflammatory drugs are medications most commonly used in alleviating the symptoms of rheumatic diseases. Cases of keratopathy (keratopathy) after indomethacin use have been reported [66], and diplopia (double vision) and amblyopia (amblyopia) after ibuprofen and naproxen treatment [67]. Antimalaric drugs such as hydroxychloroquine and more often chloroquine may aggregate in the cornea [68], in 13 - 40\% of patients causing retinopathy $[69,70]$. Gold salts - administered parenterally over the total 
dose of $1000 \mathrm{mg} / \mathrm{kg}$ of body weight - accumulate in various tissues of the body and have been observed in the eyes (conjunctiva, cornea, anterior lens and retina) in 97\% of patients [71]. Gold salt deposits in the eyes may cause hypersensitivity reactions, induce inflammation and cause marginal ulceration [72]. After methotrexate therapy diffuse irritation of the cornea is observed [73]. Chronic glucocortycoid therapy often leads to cataracts, subcapsular cataracts and glaucoma $[74,75]$.

\section{Infectious complications of the eyes in rheumatic diseases}

Viral, bacterial and fungal infectious complications occur in the organ of sight in patients with rheumatic diseases more frequently than in healthy individuals due to the immunological system dysfunctions, immunosuppressive therapy and chronic use of corticosteroids.

\subsection{Infective conjunctivitis}

\subsubsection{Bacterial conjunctivitis}

\section{Chlamydial conjunctivitis}

Reactive arthritis, which belongs to spondyloarthropaties, may be caused by infection with Chlamydia trachomatis and Chlamydia pneumoniae [76]. In the course of the infection with Chlamydia trachomatis (serotypes DK) chronic conjunctivitis occurs in 6-19\% of patients [77, 78]. Chlamydial conjunctivitis most commonly affects sexually active adults, especially men. Chlamydia DNA is detected by PCR (polymerase chain reaction) in $96 \%$ of patients with reactive arthritis concomitant conjunctivitis, leakage from the urethra and inflammation of asymmetric arthritis (former name of these symptoms is Reiter's syndrome) [79]. Eye involvement probably occurs by the way of self infection from the genitourinary system, or from one eye to another. In chlamydial conjunctivitis in adults symptoms initially occur in one of the eyes. It was also found that conjunctivitis may also occur (less frequently than in Chlamydia trachomatis) in the course of Chlamydia pneumoniae infection - as was demonstrated by confirming the presence of bacterial DNA from conjunctival scraping [80].

Clinical symptoms of chlamydial conjunctivitis in reactive arthritis are characterized by moderate redness of a single eye or less commonly of both eyes, tearing, photophobia and decreased vision. Ocular examination shows conjunctival hyperemia, chemosis and follicular reaction in conjunctiva and semilunar folds. Epithelial and subeopithelial infiltrates in cornea may develop.

The histopathology assessment reveals the presence of the chronic inflammation cells localized in submucosal layer, with the predominance of lymphocytes. In addition, fibrinogen deposits in the basal membrane of conjunctiva, infiltration of lymphocytes and macrophages around small blood vessels and lymphocytic infiltration of the walls of larger vessels of conjunctiva have been observed [81]. 
Diagnosis is based on the detection of $\operatorname{IgM}$, IgG and $\operatorname{IgA}$ antibodies to these bacteria in the blood serum by ELISA method and confirmation with W-blot test. Classical method is a detection of Chlamydia basophilic intracytoplasmic inclusions in primary cells from the conjunctival swab or conjunctival scraping using DFA (direct immunofluorescence staining) method, DNA hybridization tests or PCR (polymerase chain reaction and LCR (Ligas chain reaction).

Treatment of chlamydial conjunctivitis infection in the course of reactive arthritis consists of systemic antibiotic therapy and topical use of tetracycline, erythromycin or fluorochinolones. In systemic treatment effectiveness of macrolides (azithromycin), tetracyclines and quinolones has been shown $[82,83,84]$. Single dose of azithromycin $(1000 \mathrm{mg})$ showed efficacy in eradication of C. trachomatis infection [85] It's vital to stress that chlamydia infection is still the main cause of blindness on the African Continent. In the case of trachoma present drug of choice is azithromycin [86].

Because C.trachomatis infection is sexually transsmitted, other similarly transmitted co- infections should be considered, most commonly gonococcal.

\subsubsection{Fungal conjunctivitis}

Significantly higher incidence of fungal conjunctivitis is observed in patients with rheumatic diseases treated with systemic glucocorticoids (eg, RA) and in patients with primary Sjögren's syndrome. The most common pathogens are Candida albicans and Candida parapsilosis [87].

\section{Infectious scleritis in rheumatic diseases}

It has been shown that in patients with scleral inflammation lasting over 12 years, $7.5 \%$ of them had infectious complications, usually caused by herpes zoster virus [88]. Infectious complications can be even more frequent in patients with rheumatic diseases who are chronically treated with immunosuppressive drugs. The use of immunosuppressive drugs can cause reactivation of latent Mycobacterium tuberculosis infection which, in the form of nodular scleritis may occur in the eye [89]. There are reports of the occurrence of tuberculosis uveitis during treatment with etanercept (soluble anti TNF inhibitor) [90].

\section{Infectious keratitis in rheumatic diseases}

\subsection{Viral keratitis}

In RA patients inflammatory corneal ulceration may occur as a symptom of this disease. However, any such changes require the differentiation from herpes simplex infection, which presents the same clinical picture. The differentiation is important from the point of implemented treatment, because corneal ulceration in course of RA requires a very intensive immunosuppressive therapy, which exacerbates an inflammation caused by herpes simplex infection [91]. 


\subsection{Bacterial keratitis}

Bacterial keratitis in rheumatic diseases often is a complicated by erosive lesions of the cornea. Such changes are most commonly associated with primary and secondary Sjögren's syndrome. Most frequently - up to $73.9 \%$ - patients suffer from Gram-positive bacterial infections of as coagulase-negative Staphylococci, Staph. aureus and Spreptococcus pneumoniae. $0.3 \%$ of patients suffer from infections of Gram-negative Moraxella spp. Infections with Gram-positive bacteria are present in $17.4 \%$ of patients; most common are : Propionibacterium acnes, Corynebacterium spp. $6.5 \%$ patients reveal infections caused by Pseudomonas aeruginosa and Proteus spp [92,93].

\subsection{Fungal keratitis}

The fungal infections of the cornea may also develop in the primary and secondary Sjogren's syndrome due to improper hydration of the eye - both because of the composition of tears and rupture in the tear film. In $45.8 \%$ of patients with fungal infection of the cornea Candida albicans is the major pathogen, while Fusarium spp accouns for approximately 25\% of the infections.

\section{Comment}

In the light of the wide use of immunosuppressive therapy, in particular in the era of biological therapies in rheumatic diseases, close attention should be paid to the possible reactivation of latent infections. Most commonly tuberculous infection should be considered, but viruses like Cytomegalovirus (CMV) may also be present in patients in their persistent form. In similar circumstances - in AIDS patients and patients after organ transplantations (e.g. bone marrow transpaltation) - CMV retinitis has been reported. Currently there are reports of CMV retinitis in the course of treatment RA with infliximab (anti TNF) [94].

Finally, it should be noted that biological drugs have proved effective in the treatment of ocular manifestations of many rheumatic diseases and the exclusion of potential infection is particularly important for the choice of treatment and safety of therapy.

\section{Author details}

Brygida Kwiatkowska and Maria Maślińska*

*Address all correspondence to: maslinskam@gmail.com

Institute of Rheumatology, Poland 


\section{References}

[1] Helmic, C. G., Felson, D. T., Lawrence, R. C., et al. (2008). Estimates of prevalence of arthritis and other rheumatic conditions in the United States. Part 1. Arthritis $\mathcal{E}$ Rheumatism, 58(1), 15-25.

[2] Knox, S. A., Harrison, C. M., Britt, H. C., et al. (2008). Estimating prevalence of common chronic morbidities in Australia. Medical Journal of Australia, 189(2), 66-70.

[3] Symmons, D., Turner, G., Webb, R., et al. (2002). The prevalence of rheumatoid arthritis in the United Kingdom: New estimates for a new century. Rheumatology, 41(7), 793-800.

[4] Simonnson, M., Bergman, S., Jacobsson, L. T. H., et al. (1999). The prevalence of rheumatoid arthritis in Sweden. Scandinavian Journal of Rheumatology, 28(6), 340-343.

[5] Senna, E. R., De Barros, A. L. P., Silva, E. O., et al. (2004). Prevalence of rheumatoid diseases in Brazil: a study using the COPCORD approach. Journal of Rheumatology, 31(3), 594-597.

[6] Darmawan, J., Muirden, K. D., Valkenburg, H. A., et al. (1993). The epidemiology of rheumatoid arthritis in Indonesia. British Journal of Rheumatology, 32(7), 537-540.

[7] Aletaha, D., Neogi, T., Silman, A. J., et al. (2010). Rheumatoid arthritis classification criteria: an American College of Rheumatology/European League Against Rheumatism collaborative initiative. Arthritis Rheum, 62, 2569-2581.

[8] Cimmino, M. A., Salvarani, C., \& Macchioni, P. (2000). Extra-articular manifestations of rheumatoid arthritis. Rheumatol Int, 19(6), 213-217.

[9] Young, A., \& Koduri, G. (2007). Extra-articular manifestations and complications of rheumatoid arthritis. Best Pract Clin Rheumatol, 21(5), 907-927.

[10] Balbir-Gurman, A., Yigla, M., Nahir, A. M., et al. (2006). Rheumatoid pleural effusion. Semin Arthritis Rheum, 35, 368-378.

[11] Mac, Donald. W. J. Jr, Crawford, M. H., Klippel, J. H., et al. (1977). Echocardiographic assessment of cardiac structure and function in patients with rheumatoid arthritis. Am J Med, 63, 890-896.

[12] Genta, M. S., Genta, R. M., \& Gabay, C. (2006). Systemic rheumatoid vasculitis: a review. Semin Arthritis Rheum, 36, 88-98.

[13] Bartels, C. M., \& Bridges, A. J. (2010). Rheumatoid Vasculitis: Vanishing Menance or Target for New Treatments? Curr Rheumatol Rep, 12(6), 414-419.

[14] Harper, S. L., \& Foster, C. S. (1998). The ocular manifestation of rheumatoid disease. Int Ophtalmol Clin, 38, 1-19.

[15] Zlatanovic, G., Veselinovic, D., Cekic, S., et al. (2010). Ocular manifestation of rheumatoid arthritis-different forms and frequency. Bosn J Basic Med Sci, 10, 323-327. 
[16] Saag, K. G., Teng, G. G., Patkar, N. M., \& Et, al. (2008). American College of Rheumatology recommendations for the use of nonbiologic and biologic disease-modifying antirheumatic drugs in rheumatoid arthritis. Arthritis Rheum.; , 59, 762-784.

[17] Rudwaleit, M., van der Heijde, D., \& Landewé, R. et al. (2009). The development of Assessment of SpondyloArthritis International Society classification criteria for axial spondyloarthritis (partII)): validation and final selection. Ann Rheum Dis , 68, 777-783.

[18] Rudwaleit, M., van der Heijde, D., \& Landewé, R. et al. (2011). The development of Assessment of SpondyloArthritis International Society classification criteria for peripheral spondyloarthritis and for spondyloarthritis in general. Ann Rheum Dis , 70, 25-31.

[19] Braun, J., Bollow, M., Remlinger, G., et al. (1998). Prevalence of the spondyloarthropaties in HLA-B27 positive and negative blood donors. Arthritis \& Rheumatism, 41, 1483-1491.

[20] Saraux, A., Guillemin, F., Guggenbuhl, P., et al. (2001). Prevalence of the spondyloarthropathies in France. Ann Rheum Dis, 64, 1431-1435.

[21] Reveille, J. D. (2011). Epidemiology of Spondyloarthritis in North America. Am J Med Sci, 341(4), 284-286.

[22] Zeboulon, N., Dougados, M., \& Gossec, M. (2008). Prevalence and characteristics of uveitis in the spondyloarthropathies: a systemic literature review. Ann Rheum Dis, 67, 955-959.

[23] Lampert, J. R., \& Wright, V. (1976). Eye inflammation in psoriatic arthritis. Ann Rheum Dis, 35(4), 354-356.

[24] Bernstein, C. N., Blanchard, J. F., \& Rawsthorne, P. (2001). The prevalence of extraintenstinal diseases in inflammatory bowel disease: a population based study. Am J Gastroenterol, 96, 1116-1122.

[25] Ardizzone, S., Puttini, P. S., Cassinotti, A., \& at, . al. (2008). Extraintenstinal manifestations of inflammatory bowel disease. Givestive and Liver Disease , 40, 253-250.

[26] Lee, D. A., Barker, S. M., Su, W. P., et al. (1986). The clinical diagnosis of Reiter's syndrome. Ophthalmic and nonophthalmic aspects. Ophtalmology, 93(3), 350-356.

[27] Braun, J., van der Berg, R., \& Baraliakos, X. et al. (2010). update of the ASAS/EULAR recommendations for the management of ankylosing spondylitis. Ann Rheum Dis. $2011 ;$, 70, 896-904.

[28] Gossec, L., Smolen, J., Gaujoux-Viala, C., et al. (2012). European Legue Against Rheumatism recommendations for the management of psoriatic arthritis with pharmacological therapies. Ann Rheum Dis, 71, 4-12.

[29] Towner, S. R., Michet, C. J., O'Fallon, W. M., et al. (1983). The epidemiology of juvenile arthritis in Rochester, Minnesota, 1960-1979. Arthritis Rheum, 26(10), 1208-1213. 
[30] von, Koskull. S., Truckenbrodt, H., Holle, R., et al. (2001). Incidence and prevalence of juvenile arthritis in an urban population of southern Germany: a prospective study. Ann Rheum Dis, 60(10), 940-945.

[31] Riise, Ø. R., Handeland, K. S., Cvancarova, M., et al. (2008). Incidence and characteristics of arthritis in Norwegian children: a population-based study. Pediatrics, 121(2), 299-306.

[32] Berk, A. T., Kocak, N., \& Ünsal, E. (2001). Uveitie in Juvenile arthritis. Ocular Immunol, 9(4), 243-251.

[33] Dadoniene, J., Adamoviciute, D., Rugiene, R., et al. (2006). The prevalence of systemic lupus erythematosus in Lithuania: the lowest rate in Northern Europe. Lupus, 15(8), 544-546.

[34] Govoni, M., Castellino, G., Bosi, S., et al. (2006). Incidence and prevalence of systemic lupus erythematosus in a district of north Italy. Lupus, 15(2), 110-113.

[35] Boyer, G. S., Templin, D. W., \& Lanier, A. P. (1991). Rheumatic diseases in Alaskan Indians of the southeast coast: high prevalence of rheumatoid arthritis and systemic lupus erythematosus. Journal of Rheumatology, 18(10), 477-484.

[36] Hochberg, M. C. (1997). Updating te American College of Rheumatology revised criteria for the classification of systemic lupus erythematosus. Arthritis Rheum, 40, 725-734.

[37] Jensen, J. L., Bergem, H. O., \& Gilboe, I. M. (1999). Oral and ocular sicca symptoms and findings are prevalent in systemic lupus erythematosus. J Oral Patho Med, 28(7), 317-322.

[38] Nguyen, Q.d., \& Foster, C. S. (1998). Systemic lupus eruthematosus and the eye. Int Ophtalmol Clin, 38(1), 33-60.

[39] Bowman, S. J., Ibrahim, G. H., Holmes, G., et al. (2004). Estimating the prevalence among Caucasian women of primary Sjögrem syndrome in two general practices in Birmingham, UK. Scandinavian Journal of Rheumatology, 33(1), 39-43.

[40] Kabsakal, Y., Kitapcioglu, G., Turk, T., et al. (2006). The prevalence of Sjögren syndrome In adult women. Scandinavian Journal of Rheumatology, 35(5), 379-383.

[41] Sanchez-Guerrero, J., Perez-Dosal, M. R., et al. (2005). Prevalence of Sjögren syndrome In ambulatory patients according to the American-European Consensus Group criteria. Rheumatology, 44(2), 235-240.

[42] Vitali, C., Bombardieri, S., Jonsson, R., et al. (2002). Classification criteria for Sjögren's syndrome: a revised version of the European criteria proposed by the American-European Consensus Group. Ann Rheum Dis, 61, 554-558.

[43] Allcock, R. J., Forrest, I., Corris, P. A., et al. (2004). A study of prevalence of systemic sclerosis in northeast England. Rheumatology, 43(5), 596-602. 
[44] Le Guern, V., Mahr, A., Mouyhon, L., et al. (2004). Prevalence of systemic sclerosis in French multi-ethnic county. Rheumatology, 43(9), 1129-1137.

[45] Robinson Jr, D., Eisenberg, D., Nietert, P. J., et al. (2008). Systemic sclerosis prevalence and comorbidities in US, 2001-2002. Current Medical Research and Opinion, 24(4), 1157-1166.

[46] Subcommittee for scleroderma criteria of the American Rheumatism Association Diagnostic and Therapeutic Criteria Committee. (1980). Preliminary criteria for the classification of systemic sclerosis (scleroderma). Arthritis Rheum, 23, 581-590.

[47] West, R. H., \& Barnett, A. J. (1979). Ocular involvement in scleroderma. Br J Ophtalmol, 63(12), 845-847.

[48] Tailor, R., Herrick, A., \& Kwartz, J. (2009). Ocular manifestations of scleroderma. Survey of Ophtalmology, 54(2), 292-304.

[49] Alarcon-Segovia, D., Ibanez, G., \& Hernandez-Ortiz, J. (1974). Sjögren's syndrome in progressive systemic sclerosis (scleroderma). Am J Med, 57(1), 78-85.

[50] Kent, P. D., Michet, C. J., \& Luthra, H. S. (2004). Relapsing polychondritis. Curr Opin Rheumatol, 16(1), 56-61.

[51] Mc Adam, L. P., O’Hanlan, MA, Bluestone, R., et al. (1976). Relapsing polychondritis: prospective study of 23 patients and a review of the literature. Medicine (Baltimore), 55, 193-215.

[52] Isaak, B. L., Liesegang, T. J., \& Michet, C. J. (1986). Ocular and systemic findings in relapsing polychondritis. Ophtalmology, 93(5), 681-189.

[53] Lahmer, T., Treiber, M., von Werder, A., et al. (2010). Relapsing polychondritis:. An autoimmune disease with many faces, 9, 540-546.

[54] Cohen, R. D., Conn, D. I., \& Ilstrup, D. M. (1980). Clinical features, prognosis, and response to treatment in polyarteritis. Mayo Clini Proc, 55(3), 145-155.

[55] Hamideh, F., \& Prete, P. E. (2001). Ophtalmologic Manifestations of Rheumatic Diseases. Seminars in Arthritis and Rheumatism, 30(4), 217-241.

[56] Bullen, C. L., Liesegang, T. J., Mc Donald, T. J., et al. (1983). Ocular complications of Wegener's granulomatosis. Ophtalmology, 90(3), 272-290.

[57] Montagnac, R., Nyandwi, J., Loiselet, G., et al. (2009). Ophtalmic manifestations in Wegener's granulomatosis. Review of literature about an observation. Nephrol Ther, 5(7), 603-613.

[58] Colvard, D. M., Robertson, D. M., \& O’Duffy, J. D. (1997). The ocular manifestations of Behçet's disease. Arch Ophtalmol, 95(10), 1813-1817.

[59] Nussenblatt, R. B. (1977). Uveitis in Behçet's disease. Int Rev Immunol, 14(1), 67-79. 
[60] O'Duffy, J. D. (1990). Vasculitis in Behçet's disease. Rheum Dis Clin North Am, 16(2), 423-431.

[61] Hayreh, S. S., Podhajsky, P. A., \& Zimmerman, B. (1998). Ocular manifestations of giant cell arteritis. Am J Ophtalmol, 125(4), 506-520.

[62] Gordon, L.k., \& Levin, L. A. (1998). Visual loss in giant cel arteritis. JAMA, 280(4), 385-386.

[63] Omdal, R., Wildhagen, K., Hansen, T., et al. (2005). Anti-CD20 therapy of treatmentresistant Wegener's granulomatosis: favourable but temporary response. Scandinavian Journal of Rheumatology, 34(3), 229-232.

[64] Cheung, C. M. G., Murray, P. I., \& Savage, C. O. S. (2005). Successful treatment of Wegener's granulomatosis associated scleritis with rituximab. Br J Ophtalmol, 89(11), 1542.

[65] Hamideh, F., \& Prete, P. E. (2001). Ophtalmologic Manifestations of Rheumatic Diseases. Seminars in Arthritis and Rheumatism, 30(4), 217-241.

[66] Blaho, K. (1992). Non-steroidal anti-inflammatory drugs: current trends in pharmacology and therapeutics. J Am Optom Assoc, 63(12), 875-878.

[67] Lyle, W. M., \& Hayhoe, D. A. (1976). A literature survey of the potentially adverse effects of the drugs commonly prescribed for the elderly. J Am Optom Assoc, 47(6), 768-778.

[68] Mahoney, B. P. (1976). Rheumatologic disease and associated ocular manifestations. J Am Optom Assoc, 47(6), 403-415.

[69] Crues, A. F., Schachet, A. P., \& Nicholl, J. (1985). Chloroquine retinopathy. Ophtalmology [928], 1127-1129.

[70] Grant, S., Greenseid, D. Z., \& Leopold, I. H. (1989). Toxic retinopathies. In: Duane TD, Jaeger EA editors. Clinical Ophtalmology.Philadelphia: Lippincott.

[71] Mc Cormic, S. A., Dibartolomeo, A. G., \& Raju, V. F. (1985). Ocular chrysiasis. Ophtalmology, 92(10), 432-435.

[72] Kincaid, M. C., Green, W. R., \& Hoover, R. E. (1982). Ocular chrysiasis. Arch Ophtalmol, 100(11), 791-794.

[73] Loprinzi, C. L., Love, R. R., Garrity, J. A., et al. (1990). Cyclophosphamide, Methotrexate, and 5Fluorouracil (CMF)-Induced Ocular Toxicity. Cancer Investigation, 8(\%), 459-465.

[74] Kersey, J. P., \& Broadway, D. C. (2006). Corticosteroid-induced glaucoma: a review of the literature. Eye, 20, 407-416.

[75] Kuna, P. (1998). Longterm effects of steroid therapy. Wiad Lek, 51, 12-18. 
[76] Kwiatkowska, B., \& Filipowicz-Sosnowska, A. (2009). Reactive arthritis. Pol Arch Med. Wewn, 119(1-2), 60-66.

[77] Postema, E. J., Remeijer, L., \& van der Meijden, W. I. (1996). Epidemiology of genital chlamydial infections in patients with chlamydial conjunctivitis; a retrospective study. Genitourinary Med, 72, 203-205.

[78] Haller-Schober, E. M., \& El -Shabrawi, Y. (2002). Chlamydial conjunctivitis (in adults), uveitis, and reactive arthritis, including SARA. Best Practice $\mathcal{E}$ research Clinical Obstetrics and Gynaecology, 16(6), 815-828.

[79] Schumacher, H. R. Jr, Arayssi, T., Crane, M., et al. Chlamydia trachomatis nucleic acids can be found in the synovium of some asymptomatic subject. Arthritis and Rheumatism 199 , 42, 1281-1284.

[80] Lietman, T., Brooks, D., Moncada, J., et al. (1998). Chronic Follicular Conjunctivitis Associated with Chlamydia psitacci or Chlamydia pneumoniae. Clinical Infectious Diseases, 26, 1335-1340.

[81] Purcell, J. J., Tsai, C. C., \& Baldassare, A. E. (1982). Conjunctival Immunopathologic and Ultrastructural Alterations. Arch Ophtalmol, 100, 1618-1621.

[82] Carter, J. D., Valeriano, J., \& Vasey, F. J B. (2004). A prospective, randomized 9-monyh comparison of doxycycline and rifampin in undifferentiated spondyloarthritiswith special reference to Chlamydia-induced arthritis. J Rheumatol, 31, 973-980.

[83] Lauhio, A., Leirisalo-Repo, M., Lahdevirta, J., et al. (1991). Double-blind, placebo controlled study of free month treatment with limecycline in reactive arthritis, with special reference to Chlamydia Arthritis. Arthritis Rheum, 34, 6-14.

[84] Dreses-Werringloer, U., Padubrin, I., Zeidler, H., et al. (2001). Effects of azithromycin and rifampin on Chlamydia trachomatis infection in vitro. Antimicrob Agents Chemother, 45, 3001-3008.

[85] Katusic, D., Patricek, I., Mandic, Z., et al. (2003). Azithromycin vs doxycycline in the treatment of inclusion conjunctivitis. AM J Ophtalmol, 135(4), 447-51.

[86] West, S. K., Munoz, B., Mkocha, H., Gaydos, CA, \& Quinn, T. C. (2011). Number of years of annual mass treatment with azithromycin needed to control trachoma in hyper-endemic communities in Tanzania. J Infect Dis. Jul 15; , 204(2), 268-73.

[87] Williamson, J., Gordon, A. M., Wood, R., et al. (1968). Fungal flora of the conjunctival sac in health and disease. Brit J. Ophtal, 52, 127-137.

[88] Mc Cluskey, P. J., Watson, P. G., Lightman, S., et al. (1999). Posterior scleritis: clinical features, systemic associations, and outcome in a large series of patients. Ophtalmolo$g y, 106,380-386$.

[89] Biswas, J., Aparna, A. C., Annamalai, E., et al. (2012). Tuberculosis scleritis in a patient with rheumatoid arthritis. Ocul Immunol Inflamm, 20(1), 49-52. 
[90] Fonollosa, A., Segura, A., Giralt, J., \& Garcia-Arumi, J. (2007). Tuberculous uveitis after treatment with etanercept. Graefes Arch Clin Exp Ophthalmol, 245(9), 1397-9.

[91] Zaher, S. S., Sandinha, T., Roberts, F., et al. (2005). Herpes Simplex Keratitis Misdiagnosed as Rheumatoid Arthritis-Related Peripheral Ulcerative Keratitis. Cornea, 24(8), 1015-1017.

[92] Bourcier, T., Thomas, F., Borderie, V., et al. (2003). Bacterial keratitis: predisposing factors, clinical and microbiological review of 300 cases. Br J Ophtalmol, 87, 834-838.

[93] Schafer, F., Bruttin, O., Zografos, L., et al. (2001). Bacterial keratitis: a prospective clinical and microbiological study. Br J Ophtalmol, 85, 842-847.

[94] Hearter, G., Manfras, B. J., de jong-Hesse, Y., et al. Cytomegalovirus retinitis in patient treated with anti-tumor necrosis factor alpha antibody therapy for rheumatoid arthritis. Clin. Infect.Dis, 39(9), 88-94. 